International Journal of Agriculture, Environment and Bioresearch

Vol. 5, No. 04; 2020

ISSN: $2456-8643$

\title{
UTILIZATION OF MEDICINAL PLANTS IN MALARIA TREATMENT AMONG RURAL DWELLERS IN OYO STATE, NIGERIA
}

\author{
Oke, O.O. ${ }^{1}$, Banmeke, T.O.A. ${ }^{2}$, *Adeoye, A.S. ${ }^{1}$ and Ajayi, O.B. ${ }^{3}$ \\ ${ }^{1}$ Department of Agricultural Extension and Management, Federal College of Forestry, P.M.B. 5087, Jericho Hills, \\ Ibadan, Nigeria \\ ${ }^{2}$ Department of Agricultural Extension and Rural Development, Federal University of Agriculture, Abeokuta, \\ Nigeria \\ ${ }^{3}$ Department of Forest Products Development and Utilisation, Forestry Research Institute of Nigeria.
}

https://doi.org/10.35410/IJAEB.2020.5543

\begin{abstract}
This study investigated the utilization of medicinal plants in the treatment of malaria among rural dwellers in Oyo State. A well structured questionnaire with interview schedule was used to obtain primary data from 240 rural dwellers selected through multi stage sampling procedure. Data were obtained on common medicinal plants used in malaria treatment, parts and forms of its use, and factors influencing its use. Data were analyzed using descriptive statistics, and Analysis of Variance. Findings revealed that a total of 38 species of medicinal plants were used by rural dwellers in malaria treatment, out of which Azadirachta indica, Chromolaena odorata, Mangifera indica, Carica papaya and Cymbopogon citrate the most were commonly used. Results revealed that medicinal plant parts frequently used by the respondents were leaves of Chromolaena odorata (95.4\%), Cymbopogon citrates (94.2\%), Henna plant (94.2\%), Phyllantus amarus $(87.5 \%)$, Momordica charantia (86.7\%), and Azadirachta indica (84.6\%). Also, $91.0 \%$ of the respondents indicated that extract from the leaves of the plants were consumed in liquid form after boiling. Furthermore, efficacy of herbal medicine $(87.1 \%)$, indigenous knowledge of medicinal plants $(82.1 \%)$, and availability of medicinal plants $(65.8 \%)$ were the major factors that informed the use of these plants for malaria treatment. Majority $(88.3 \%)$ of the rural dwellers consumed medicinal plants more than twice daily for malaria treatment. Result of ANOVA showed a significant difference $(\mathrm{p}<0.05)$ in parts of medicinal plants $(\mathrm{F}=12.435)$ and forms of medicinal plants $(\mathrm{F}=16.345)$ used by respondents in the study area. The study concluded that the commonly used medicinal plants for malaria treatment in the study area were Azadirachta indica, Chromolaena odorata, Henna plant, Gossypium barbadense and Cymbopogoncitrates. It was recommended that concerted efforts be made in developing malaria drugs locally from these identified plants.
\end{abstract}

Keywords: utilization, medicinal plants, malaria, treatment.

\section{INTRODUCTION}


Vol. 5, No. 04; 2020

ISSN: $2456-8643$

An understanding of the trend of the health status of rural dwellers with the various prevailing conditions that actually aggravate their plight is of paramount importance. The exposure of rural dwellers to diseases and health disorders impairs their physical performance and equally affect their ability to fully utilize all inputs at their disposal. It is therefore important to note that good health and productive agriculture are important in the economy of any nation especially in the fight against poverty. Traditional medicine is the sum total knowledge, skills, and practices based on the theories, beliefs and experiences, indigenous to different cultures, whether explicable or not, used in the maintenance of health as well as in the prevention, diagnosis, improvement or treatment of physical and mental illness (Federal Ministry of Health -WHO, 2014).

Malaria is one of the important tropical diseases that has attracted a lot of attention and is one of humanity's worst diseases and the suffering it causes is now a global crisis. One fifth of the world population is at risk of malaria and there are more than 300 million cases each year (WHO 1998). The annual death rate has been recorded at between 1.2 and 2.7 million every year. Its area of spread covers more than 100 tropical countries and its control remains a major concern for improved healthcare worldwide. Majority (about 90\%) of malaria cases are in sub-Saharan Africa and Plasmodium falciparum is the main cause of severe clinical malaria and eventual deaths (Adekunle, 2008). Malaria remains a serious public health challenge and causes death and illnesses in children in Nigeria (Uzochukwu, Ogochuckwu, Uloaku, Obinna and Florence, 2010). According to the latest estimates by the WHO, there were about 219 million cases of malaria in 2010 and an estimated 660, 000 with most malaria deaths occurring in Africa with the Republic of Congo and Nigeria accounting for $40 \%$ of the deaths globally (WHO, 2013). Most of these deaths occur in children below the age of five due to low levels of immunity and poverty which makes it difficult for the parents of such children to obtain drugs for treatment (Ansah, Gyapong, Agyepong and Evans, 2001; Ricci, 2012). This has led to the use of alternative herbal concoctions in rural communities (Buabeng, Duwiejua, Dodoo,Matowe and Enlund, 2007).

It is estimated that malaria could be responsible for an average annual reduction of $1.3 \%$ in economic growth in Africa with many families spending a significant portion of their income on treating it (WHO 2006). Children are more susceptible to malaria attacks during the first five years of life due to inadequate immunity (Frey et al 2006, WHO 2006). However, there is usually inappropriate treatment of malaria at home due to poor knowledge of causation and transmission of malaria as well as types and dosage of drugs used (Ajayi 2005, Falade et al 2005). Hence, deterioration of initial uncomplicated malaria to complicated one leading to death of a very large number of the under-five children (Falade et al 2006, Orimadegun 2010). Notwithstanding, some scholars across countries have carried out several researches on the use of medicinal plants in the treatment of malaria among people. Herbal medicines remain part of the history of the people despite the fact that orthodox medicines which came with colonization, appear to have occupied the centre stage in the treatment of diseases especially in modern medical practice (Osemene et al., 2011). Meanwhile, the present unprecedented global upsurge of interest in herbal medicine is perhaps a measure of a more realistic perception of the limitations of orthodox medicines in terms of cost, accessibility, effectiveness and safety (Moody, 2007). Pharmanews, (2010) stated that in Nigeria, medical practitioners especially physicians still have some reservations prescribing herbal medicines for their patients. Various studies have also pointed out the potential of plants for integrating medicinal plants and folklore into regular medical practices and that several compounds that are now used in modern 
Vol. 5, No. 04; 2020

ISSN: $2456-8643$

pharmaceutical systems have been elucidated and validated from extracts of plants used in folklore therapies. (Akiyemi et al. 2005, Aslam 2002, Atindehou, Kone, Terreaux, Traore, Hostettmann and Dosso 2002, Dewick 2002, Healy and Aslam 2002 and Williamson, 2002).

In the study carried out by Burcher (2003), he found out that many rural communities have great faith in traditional medicine, particularly the inexplicable aspects as they believe that it is the wisdoms of their forefathers which also recognize their socio-cultural and religious background which orthodox medicine seems to neglect.

\section{Problem statement}

The introduction of western education, modern religious beliefs and increased contact with the global community has become the integral part of rural communities. However, the rural dwellers taboos', traditions and customs have been affected and in some instances led to the abandonment of the use of medicinal plants for treating ailments and therefore traditional medicine may not retain the significance it once held (Kiringe and Okello 2005 and Sindiga, 1995). Furthermore, there has not been any significant improvement in the health status of the rural dwellers as the level of poverty in the rural areas is on the increase. This has led to unaffordable use of orthodox medicine with their resultant preference for herbal medicine which is affordable and available. There is also the high prevalence of malaria in the study areas due to lack of access to quality health services that could provide them with orthodox medicine. There is also the cost and side effects of orthodox medicine. Most Nigerians, especially those living in rural communities do not have prompt access to orthodox medicine due to unavailability of medical practitioners in most rural communities. It is estimated that about $75 \%$ of the populace still prefers to solve their health problems consulting traditional healers (Awudu, 2000). Several rural dwellers depend on traditional herbal medicine for treatment of many infectious diseases. The use of plants for medicinal purpose over the years is not new. Among some tribes, especially Yorubas, medicinal plants are valued and have elements of mysticism attached to them (Odugbemi, 2008). A number of plants like Neem, Lemon grass, Hog weed, Pigeon pea and Pawpaw have been used in traditional medicine for many years. Based on the backdrop, the following specific objectives were derived; identification of common medicinal plants used for the treatment of malaria; determination the parts and forms of medicinal plants used for the treatment of malaria; and determination of the factors that influence the use of medicinal plants among rural dwellers. The research hypothesis of the study shows that there is no significant difference between the parts and forms of medicinal plants used by the respondents in the treatment of malaria across the three agro-ecological zones of Oyo state.

Research design

The study was carried out in Oyo state within latitude 6 $6^{\circ} 55^{\prime}-045^{\prime}$ and longitude 20 50'-3056' Southwest Nigeria respectively. The population of the study was the rural dwellers in the three agro-ecological zones of Oyo state. Multistage sampling procedure was used for the selection of respondents from the zones namely; guinea savannah, derived savannah, and lowland rainforest. One local government was selected randomly from each zone making three (3) LGAs in all which are Iseyin, Atiba, and Ido respectively. The second stage involved random selection of $30 \%$ of wards from 10 wards in each Local Government selected, making total of nine (9) wards from the 3 LGAs. The $3^{\text {rd }}$ stage involved random selection of 6 villages from 3 wards in Iseyin, 4 villages from 3 wards in Atiba, and 5 villages from 3 wards in Ido respectively. The $4^{\text {th }}$ stage involved the systematic random selection of respondents from each selected villages with 21,11 , 
and 14 respectively. A total of 240 respondents were selected for the study. A well structured questionnaire was used for data collection in the study area while data were analyzed with descriptive and inferential statistics such as frequencies, simple percentages and analysis of variance.

\section{RESULTS AND DISCUSSION}

\section{Common medicinal plants used by the rural dwellers for malaria treatment}

Table 1 reveals that 42 species of plants made up of 23 families were noted to be used in the treatment of malaria by the rural dwellers in the study area. These plants were used singly or in combination with other herbal materials in the fresh or dried forms. The mode of consumption is mostly oral by drinking the extracts or concoctions. These finding tallies with other studies such as Colfer et al., (2006) on the use of forest plants to treat some tropical diseases that some pharceutical components like quinine were extracted from Cinchona spp for the treatment of malaria. The most frequently mentioned plants and leaves used for the treatment of malaria by the respondents in Oyo state were Dogonyaro - Neem (Azadirachta indica), Ewe Akintola (Chromolaena odorata), Mango leaves (Mangifera indica), Pawpaw (Carica papaya), Orange leaves, lemon grass, cashew leaves, and some local resource(s) added to it. The people rural dwellers have learned the medicinal values of leaves, root and bark of trees from each other. However, the elderly people in the village were believed to have more experience than the younger ones.

Result of in-depth interview revealed that;

A 65 year old grandfather in Ekunle 1 argued that "almost everybody in this village is a healer. We all know the kind of leaves, plants or root to assemble to treat malaria either in children, youth or adult".

Table 1: Common medicinal plants used by the rural dwellers for malaria treatment $(n=$ 240)

\begin{tabular}{|lllll|}
\hline S/No & Common names & Local names & Scientific Name (Species) & Family Names \\
\hline 1. & Akee-apple & Isin & Blighia sapida & Sapindaceae \\
2. & Bernuda grass & Esekanakana & Cynodon dactylon & Poeceae \\
3. & African cucumber & Ejirin wewe & Momordica charantia & Cucurbitaceae \\
4. & Mahogany & Oganwo, Apa-igbo & Khaya grandifoliola & Meliaceae \\
5. & Worm wood & Ewe imi & Artemisia absinthium & Asteraceae \\
6. & Senna & Kasia & Senna siamea & Caesalpiniaceae \\
7. & Baobab & Ose & Adasonia digitata & bombacaceae \\
8. & Neem & Dogonyaro & Azadirachta indica & Meliaceae \\
9. & Mango & Mangoro & Mangifera indica & Anacardiaceae \\
10. & Sausage nut & Pandoro & Kigelia pinnata & Bignomiuceae \\
11. & Siam weed & Ewe Akintola & Chromolaena odorata & Compositae \\
& & Ewe Awolowo & & \\
12. & Pawpaw & Ibepe & Carica papaya & Caricaceae \\
13. & Giant milkweed, & Bomubomu & Calotropis gigantea & Asclepiadaceae \\
& Sodom apple & & &
\end{tabular}


International Journal of Agriculture, Environment and Bioresearch

Vol. 5, No. 04; 2020

ISSN: $2456-8643$

\begin{tabular}{|c|c|c|c|c|}
\hline S/No & Common names & Local names & Scientific Name (Species) & Family Names \\
\hline 14. & Guava & Gilofa & Psidium guajava & Myrtaceae \\
\hline 15. & $\begin{array}{l}\text { Haemorrhage } \\
\text { plant }\end{array}$ & Yunyun & Aspilia Africana & Asteraceae \\
\hline 16. & Asthma weed & Emi-ile & Parietaria judaica & Urticaceae \\
\hline 17. & Physic nut & Lapalapa & Jatropha curcas & Euphorbiaceae \\
\hline 18. & Sand paper tree & Ewe ipin & Ficus coronata & Moraceae \\
\hline 19. & Lime & Osan wewe & Citrus aurantifolia & Rutaceae \\
\hline 20. & Pigeon pea & Otili & Cajanus cajan & Fabaceae \\
\hline 21. & Grape & Osan gerepu & Citrus paradisi & Rutaceae \\
\hline 22. & Cocoa & Koko & Theobroma cacao & Malvaceae \\
\hline 23. & Cotton & Owu & Gossypium barbadense & Malvaceae \\
\hline 24. & Tree of life & Ewe Akoko & Newbouldia laevis & Bignoniaceae \\
\hline 25. & Iyeye & Iyeye & Spondias monbin. L. & Anacardiaceae \\
\hline 26. & Yanni & Igi Awopa & Annickia (syn. Enantia) & annonaceae \\
\hline 27. & N/A & Igi Ogbon & Parquetina nigrescens & Asclepiadaceae \\
\hline 28. & Hygrophilia & Mofowokanmi & Acathospermum hispidum & Acanthaceae \\
\hline 29. & Calabash & Igi Sogba & Crescentia cujete & Bignoniaceae \\
\hline 30. & Palm family & Igi Agbon & Cocos nucifera & Arecaceae \\
\hline 31. & N/A & & Hyptis suaveolens & Labiatae \\
\hline 32. & Gliricidia & Igi Agumaniye & Gliricidia sepium & Fabaceae \\
\hline 33. & Brimstone tree & Oruwo & Morinda lucida & Rubiaceae \\
\hline 34. & Bitter leaf & Ewuro & Vernonia amygdalina & Compositae \\
\hline 35. & African star apple & Agbalumo & Chrysophyllum albidum & Sapotaceae \\
\hline 36. & Cashew-nut tree & Kasu & Anacardium occidentale & Anacardaceae \\
\hline 37. & Lemon grass & Kooko-Oba & Cymbopogon citratus & Poaceae \\
\hline 38 & Phyllantus amurus & Eyin Olobe & Phallantus amurus & \\
\hline
\end{tabular}

Source: Field survey (2014).

Parts and forms of medicinal plants used among the rural dwellers

Traditionally different parts of plants are taken for medicinal purpose such as the leaves, barks, stems or roots. Table 2 reveals that the part of medicinal plants frequently used by the respondents were the leaves of Akintola (Chromolaena odorata) (95.4\%), lemon grass (Cymbopogon citrates) (94.2\%), Henna plant (94.2\%), cotton (Gossypium barbadense) (90.0\%), Eyin olobe (Phyllantus amurus) (87.5\%), African cucumber (Momordica charantia) (86.7\%), dogonyaro (Azadirachta indica) (84.6\%), Oruwo (morinda lucida) (81.7\%). lime (Citrus aurantifolia) (78.3\%), and pawpaw (Carica papaya) $(77.5 \%)$. 
Table 2: Parts of medicinal plant used by the rural dwellers in the study area $(n=240)$

\begin{tabular}{|c|c|c|c|c|c|c|c|c|}
\hline Medicinal plants* & $\mathrm{L}(\%)$ & B (\%) & $\mathrm{R}(\%)$ & $\mathrm{L} / \mathrm{B}(\%)$ & $\mathrm{L} / \mathrm{R}(\%)$ & $\mathrm{L} / \mathrm{B} / \mathrm{R}(\%)$ & Seed & $\begin{array}{l}\text { No } \\
\text { Response }\end{array}$ \\
\hline Lemon grass & $226(94.2)$ & - & - & - & - & - & - & $14(5.8)$ \\
\hline Neem tree & 203(84.6) & - & - & $16(6.7)$ & $6(2.5)$ & $15(6.2)$ & - & - \\
\hline Pawpaw & $186(77.5)$ & - & - & $3(1.2)$ & $9(3.8)$ & $3(1.2)$ & $39(16.3)$ & - \\
\hline Mango & $55(22.9)$ & $4(1.7)$ & - & $161(67.1)$ & $6(2.5)$ & $14(5.8)$ & - & - \\
\hline Akee-apple & $48(20.0)$ & $7(2.9)$ & - & $8(3.3)$ & - & - & - & $177(73.8)$ \\
\hline Mahogamy & $38(15.8)$ & $3(1.2)$ & - & $1(0.4)$ & - & - & - & $198(82.6)$ \\
\hline Bermuda grass & $30(12.5)$ & - & $5(2.1)$ & - & - & - & - & $205(85.4)$ \\
\hline $\begin{array}{l}\text { African } \\
\text { cucumber }\end{array}$ & 208(86.7) & - & - & - & - & - & - & $32(13.3)$ \\
\hline Worm wood & 47 (19.6) & - & - & - & - & - & - & 193(80.4) \\
\hline Cashew-nut tree & $94(39.2)$ & $9(3.8)$ & $8(3.3)$ & $7(2.9)$ & - & $7(2.9)$ & - & $115(47.9)$ \\
\hline Lemonade tree & $55(22.9)$ & $7(2.9)$ & - & - & - & $6(2.5)$ & $3(1.2)$ & $169(70.5)$ \\
\hline Sausage nut & $31(12.9)$ & - & - & $4(1.7)$ & - & - & $8(3.3)$ & 197(82.1) \\
\hline Giant milk weed & $22(9.2)$ & - & - & - & - & - & - & $218(90.8)$ \\
\hline $\begin{array}{l}\text { Haemorrhage } \\
\text { plant }\end{array}$ & $50(20.8)$ & - & - & - & - & - & - & 190(79.2) \\
\hline Bamboo & $170(70.8)$ & - & - & - & - & - & - & $70(29.2)$ \\
\hline Asthma weed & $26(10.8)$ & $3(1.2)$ & - & - & - & - & - & $211(88.0)$ \\
\hline Physic nut & $99(41.2)$ & - & $8(3.3)$ & - & $6(2.5)$ & - & - & $127(53.0)$ \\
\hline Henna plant & $226(94.2)$ & - & - & - & - & $4(1.7)$ & - & $10(4.1)$ \\
\hline Sand paper tree & $84(35.0)$ & - & - & - & $9(3.8)$ & - & - & $147(61.2)$ \\
\hline Akintola & $229(95.4)$ & - & - & - & - & - & - & $11(4.6)$ \\
\hline Cotton & $216(90.0)$ & - & - & $4(1.7)$ & - & - & - & $20(8.3)$ \\
\hline Pigeon pea & $116(48.3)$ & $11(4.6)$ & - & $3(1.2)$ & - & - & - & $110(45.9)$ \\
\hline Cocoa & $48(20.0)$ & $62(25.8)$ & - & $20(8.3)$ & - & - & - & $110(45.9)$ \\
\hline
\end{tabular}


Vol. 5, No. 04; 2020

ISSN: $2456-8643$

\begin{tabular}{|c|c|c|c|c|c|c|c|c|}
\hline Guava & $142(59.2)$ & $5(2.1)$ & - & $30(12.5)$ & $2(0.8)$ & - & - & $61(25.4)$ \\
\hline Phyllantus & $210(87.5)$ & $1(0.4)$ & - & $4(1.7)$ & - & - & - & $25(10.4)$ \\
\hline $\begin{array}{l}\text { Newbouldia } \\
\text { leavis }\end{array}$ & $92(38.3)$ & $4(1.7)$ & $4(1.7)$ & - & $4(1.7)$ & - & - & $136(56.6)$ \\
\hline Ijan & $104(43.3)$ & $1(0.4)$ & - & - & - & - & - & $135(56.3)$ \\
\hline Cassia & $131(54.6)$ & & $2(0.8)$ & $2(0.8)$ & - & - & - & $105(43.8)$ \\
\hline Igi awopa & $73(30.4)$ & $4(1.7)$ & - & - & - & - & - & $163(67.9)$ \\
\hline Igi ogbon & $59(24.6)$ & $7(2.9)$ & - & - & - & - & - & $174(72.5)$ \\
\hline Morinda lucida & 196(81.7) & $2(0.8)$ & - & $7(2.9)$ & $15(6.2)$ & $10(4.2)$ & $1(0.4)$ & $9(3.8)$ \\
\hline Lime & $188(78.3)$ & $4(1.7)$ & - & $4(1.7)$ & $7(2.9)$ & - & $16(6.7)$ & $21(8.7)$ \\
\hline $\begin{array}{l}\text { Chrysophyllum } \\
\text { albidum }\end{array}$ & $60(25.0)$ & $17(7.1)$ & $3(1.2)$ & $10(4.2)$ & $3(1.2)$ & - & - & $147(61.3)$ \\
\hline Spondia mombin & $59(24.6)$ & & - & $8(3.3)$ & - & - & - & $173(72.1)$ \\
\hline Mafowokanmi & $23(9.6)$ & $4(1.7)$ & - & $1(0.4)$ & - & - & - & $212(88.3)$ \\
\hline Coconut & $18(7.5)$ & 91(37.9) & - & $2(0.8)$ & $3(1.2)$ & - & - & $126(52.6)$ \\
\hline Gliricidia sepium & $54(22.5)$ & $6(2.5)$ & - & - & - & - & - & $180(75.0)$ \\
\hline Grape & $98(40.8)$ & $3(1.2)$ & - & - & - & - & $112(46.7)$ & $27(11.3)$ \\
\hline Igi sogba & $24(10.0)$ & - & - & - & - & - & - & $216(90.0)$ \\
\hline Patanma & $8(3.3)$ & $3(1.2)$ & - & - & - & - & - & $229(95.5)$ \\
\hline Fig tree & $2(0.8)$ & - & - & - & - & - & - & $238(99.2)$ \\
\hline
\end{tabular}

Source: Field survey (2014)

* = Multiple response

Key: L = Leaf, $\quad \mathrm{B}=$ Bark, $\quad \mathrm{R}=$ Root, $\mathrm{L} / \mathrm{B}=$ Leaf $/$ Bark, $\quad \mathrm{L} / \mathrm{R}=$ Leaf $/ \mathrm{Root}, \quad \mathrm{L} / \mathrm{B} / \mathrm{R}=$ Leaf/Bark/Root

Table 3 also reveals that most of the plants are consumed in liquid forms by the respondents after boiling such as, mango (97.1\%), henna plant (93.5\%), neem tree (93.3\%), lemon grass and Akintola (91.7\%), lime (91.2\%), cotton (90.8\%), morrinda lucida (89.6\%), phyllantus (87.9\%), pawpaw (86.7\%). The result implies that very few of the respondents take the plants both in liquid and powder forms. However, most of the respondents take mixture of leaves, barks and plants together for treatment of malaria in liquid or powder form.Majority of them believedmedicinal plants parts to be more effective in the treatment of malaria.

The statements by one of the respondents through in- depth interview was captured below as: 
Vol. 5, No. 04; 2020

ISSN: $2456-8643$

"Everybody in this rural area knows that I and my children don't go to the hospital for the treatment of malaria at all and that most modern drugs are extracts from local trees and plants, since I have the indigenous knowledge (IK) inherited from my father's pertaining to the medicinal plant used in the treatment of malaria, I utilized it and I get good results all the time."'This also agrees with a report by the World Health Organization in Nigeria, Gambia, Ghana and Mali that more than $60 \%$ of children with malaria are treated at home with indigenous medicines (Abdullahi, 2011).

Table 3: Forms of medicinal plants used by the rural dwellers in the study area. $(n=240)$

\begin{tabular}{|lllll|}
\hline Medicinal Plants* & Liquid (\%) & Powder (\%) & Both (\%) & $\begin{array}{l}\text { No } \\
\text { Response }\end{array}$ \\
\hline Lemon grass & $220(91.7)$ & - & $3(1.2)$ & $17(7.1)$ \\
Neem tree & $224(93.3)$ & - & $7(2.9)$ & $9(3.8)$ \\
Pawpaw & $208(86.7)$ & $4(1.7)$ & - & $28(11.6)$ \\
Mango & $233(97.1)$ & - & - & $7(2.9)$ \\
Akee-apple & $54(22.5)$ & - & - & $186(77.5)$ \\
Mahogamy & $42(17.5)$ & - & - & $198(82.5)$ \\
Bermuda grass & $25(10.4)$ & - & - & $215(89.6)$ \\
African cucumber & $200(83.3)$ & - & - & $40(16.7)$ \\
Worm wood & $56(23.3)$ & - & - & $184(76.7)$ \\
Cashew-nut tree & $117(48.8)$ & - & - & $123(51.2)$ \\
Lemonade tree & $64(26.7)$ & - & - & $176(73.3)$ \\
Sausage nut & $34(14.2)$ & - & - & $206(85.8)$ \\
Giant milk weed & $23(9.6)$ & - & - & $217(90.4)$ \\
Haemorrhage plant & $37(15.4)$ & - & - & $203(84.6)$ \\
Bamboo & $170(70.8)$ & - & - & $70(29.2)$ \\
Asthma weed & $41(17.1)$ & $3(1.2)$ & - & $196(81.7)$ \\
Physic nut & $100(41.7)$ & - & - & $140(58.3)$ \\
Henna plant & $225(93.5)$ & - & - & $15(6.5)$ \\
& & & &
\end{tabular}


International Journal of Agriculture, Environment and Bioresearch

Vol. 5, No. 04; 2020

ISSN: $2456-8643$

\begin{tabular}{|c|c|c|c|c|}
\hline Sand paper tree & $105(43.5)$ & - & - & $135(56.5)$ \\
\hline Akintola & $220(91.7)$ & - & - & $20(8.3)$ \\
\hline Cotton & $218(90.8)$ & - & - & $22(9.2)$ \\
\hline Pigeon pea & $97(40.4)$ & - & - & $143(59.6)$ \\
\hline Cocoa & $130(54.2)$ & - & - & $110(45.8)$ \\
\hline Guava & $185(77.1)$ & - & - & $55(22.9)$ \\
\hline Phyllantus & $211(87.9)$ & - & - & $29(12.1)$ \\
\hline Newbouldia leavis & $93(38.8)$ & - & - & $147(61.2)$ \\
\hline Ijan & $111(46.2)$ & - & - & $129(53.8)$ \\
\hline Cassia & $146(60.8)$ & - & - & $94(39.2)$ \\
\hline Igi awopa & $59(24.6)$ & - & - & $181(75.4)$ \\
\hline Igi ogbon & $54(22.5)$ & - & - & $186(77.5)$ \\
\hline Morinda lucida & $215(89.6)$ & - & - & $25(10.4)$ \\
\hline Lime & $219(91.2)$ & - & - & $21(8.8)$ \\
\hline Chrysophyllum albidum & $93(38.8)$ & - & - & $147(61.2)$ \\
\hline Spondia mombin & $70(29.2)$ & - & - & $170(70.8)$ \\
\hline Mafowokanmi & $20(8.3)$ & $3(1.2)$ & - & $217(90.5)$ \\
\hline Coconut & 119 (49.6) & $2(0.8)$ & - & $119(49.6)$ \\
\hline Gliricidia sepium & $65(27.1)$ & - & - & $175(72.9)$ \\
\hline Grape & $199(82.9)$ & - & - & $41(17.1)$ \\
\hline Igi sogba & $39(16.2)$ & - & - & $202(83.8)$ \\
\hline Patanma & $18(7.5)$ & - & - & $222(92.5)$ \\
\hline Igi ajadi & - & - & - & $240(100.0)$ \\
\hline Fig tree & $2(0.8)$ & - & - & 238(99.2) \\
\hline
\end{tabular}

Source: Field survey (2014) $\quad *=$ Multiple response 


\section{Factors that influence the use of medicinal plants among rural dwellers}

Table 4 reveals the factors that really influence utilization of medicinal plants by majority of rural dwellers in Oyo state as; efficacy in the use of herbal medicine (2.84), high indigenous knowledge of medicine plants (2.73), strong belief in herbal medicine(2.71), ready availability of medicinal plants (2.49) and cheap cost of medicinal plants when compared with orthodox medicine (2.44). The overall wellbeing of rural dwellers is very essential in achieving sustainable rural development and for maximum agricultural productivity since the rural dwellers engaged in farming as their main source of income. The result also implies that influencing factors serve as a motivation among the rural dwellers to utilize medicinal plants.

Table 4: Distribution based on factors that influence the use of medicinal plants among rural dwellers $(n=240)$

\begin{tabular}{|c|c|c|c|c|c|c|}
\hline & Variables & $\begin{array}{l}\text { Major } \\
\text { factor } \\
(\%)\end{array}$ & $\begin{array}{l}\text { Minor } \\
\text { factor } \\
(\%)\end{array}$ & $\begin{array}{l}\text { Not a } \\
\text { factor } \\
(\%)\end{array}$ & Mean & Rank \\
\hline $\mathrm{i}$ & The efficacy of herbal medicine & $209(87.1)$ & $24(10.0)$ & $7(2.9)$ & 2.84 & $\mathbf{1}^{\text {st }}$ \\
\hline ii & $\begin{array}{l}\text { The indigenous knowledge on medicinal } \\
\text { plants is high. }\end{array}$ & $197(82.1)$ & $22(9.2)$ & $21(8.8)$ & 2.73 & $2^{\text {nd }}$ \\
\hline iii & Strong belief in herbal medicine & $194(80.8)$ & $23(9.6)$ & $23(2.6)$ & 2.71 & $3^{\text {rd }}$ \\
\hline iv & Medicinal plants are readily available. & $158(65.8)$ & $41(17.1)$ & $41(17.1)$ & 2.49 & $4^{\text {th }}$ \\
\hline $\mathrm{v}$ & $\begin{array}{l}\text { Use of medicinal plants cost less when } \\
\text { compared with orthodox medicine. }\end{array}$ & $146(60.8)$ & $53(22.1)$ & $41(17.1)$ & 2.44 & $5^{\text {th }}$ \\
\hline vi & $\begin{array}{l}\text { Due to the popularity of the use of } \\
\text { medicinal plants. }\end{array}$ & $140(58.3)$ & $58(24.2)$ & $42(17.5)$ & 2.41 & $6^{\text {th }}$ \\
\hline vii & $\begin{array}{l}\text { Herbal medicine is more effective than } \\
\text { orthodox medicine }\end{array}$ & $118(49.2)$ & $45(18.8)$ & $77(32.1)$ & 2.17 & $7^{\text {th }}$ \\
\hline viii & Preference for taste. & $91(37.9)$ & $52(21.7)$ & $97(40.4)$ & 1.98 & $8^{\text {th }}$ \\
\hline ix & Lack of orthodox medicine. & $71(29.6)$ & $76(31.7)$ & $93(38.8)$ & 1.91 & $9^{\text {th }}$ \\
\hline $\mathrm{x}$ & Lack of trust in orthodox medicine & $47(19.6)$ & $76(31.7)$ & $117(48.8)$ & 1.71 & $10^{\text {th }}$ \\
\hline $\mathrm{xi}$ & $\begin{array}{l}\text { Medicinal plants usage does not have } \\
\text { specified dosage. }\end{array}$ & $59(24.6)$ & $53(22.1)$ & $128(53.3)$ & 1.71 & $10^{\text {th }}$ \\
\hline xii & $\begin{array}{l}\text { The side effects on the use of medicinal } \\
\text { plants are high. }\end{array}$ & $32(13.3)$ & $48(20.0)$ & $160(66.7)$ & 1.47 & $11^{\text {th }}$ \\
\hline xiii & Unavailability of modern drugs. & $24(10.0)$ & 43 (17.9) & $173(72.1)$ & 1.38 & $12^{\text {th }}$ \\
\hline xiv & Religious belief & $32(13.3)$ & $13(5.4)$ & $195(81.2)$ & 1.32 & $13^{\text {th }}$ \\
\hline $\mathrm{xv}$ & Modern health care is inaccessible. & $19(7.9)$ & $33(13.8)$ & $188(78.3)$ & 1.30 & $14^{\text {th }}$ \\
\hline
\end{tabular}

Source: Field survey (2014).

Hypothesis of the study

There is no significant difference between the parts and forms of medicinal plants used by the respondents in the treatment of malaria across the three agro-ecological zone of Oyo states.

The result of ANOVA presented in Table 5 showed a significant difference in the parts of medicinal plants $(\mathrm{F}=12.435, \mathrm{p}<0.05)$ and forms of medicinal plants $(\mathrm{F}=16.345, \mathrm{p}<0.05)$ used 
by the respondents in the agro-ecological zones of Oyo state. This indicated that the parts of medicinal plants used by the rural dwellers in the treatment of malaria was different across the agro-ecological zones and also the forms of utilizing these plants were not the same across the three agro-ecological zones of the state. This may be adduced to the different plants readily available in the different agro-ecological zones. This means that the stated hypothesis is rejected.

Table 5: Test of means of medicinal plants parts and forms of medicinal plants used by the respondents for the treatment of malaria across agro-ecological zones of Oyo State

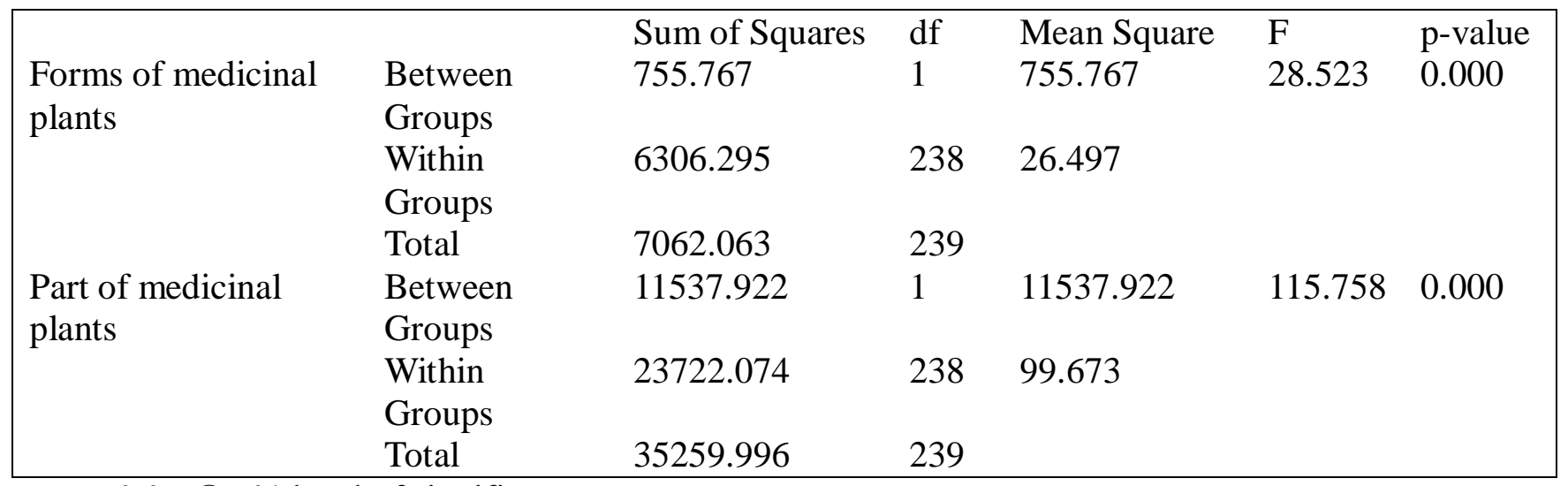

$\mathrm{P} \leq 0.05 @ 5 \%$ level of significance

\section{CONCLUSION}

The findings revealed that the commonly used medicinal plants for malaria treatment among rural dwellers in Oyo state were Azadirachta indica, Chromolaena odorata, Henna plant, Gossypium barbadense and Cymbopogoncitrates. The most frequently used parts was the leaves. However, utilization was influenced by cheap and readily available medicinal plants in liquid and powder extracts from the leaves, barks, and roots, the high indigenous knowledge of medicinal plants and their efficacy to treating malaria.

\section{RECOMMENDATION}

There should be concerted efforts in the development of malaria drugs locally from these identified plants. Also, government and non-governmental organizations should synergize to conserve, sustain, and multiply these herbal gene banks across the ecological zone in the country.

\section{REFERENCES}

Abdullahi, A.A. 2011. Towards a Sociology of Health care service utilization in the case of children with malaria in Nigeria. Unpublished Ph.D Thesis submitted to the Department of Sociology, Faculty of Humanities, University of Johannesburg

Adekunle, M.F. 2008. Indigenous uses of plant leaves to treat malaria fever at Omo forest Reserve (OFR) Ogun State, Nigeria. Journal of Enviornmental Studies and Management 1(1):31. 
Ajayi I .O. 2005. Development and assessment of a treatment guideline to improve home management of malaria in Ona-Ara Local Government Area of Oyo State. Unpublished PhD Thesis submitted to Department of Public Health, University of Ibadan 2005.

Akiyemi, K.O., O. Oladapo, C.E. Okwara, C.C. Ibe \& K.A. Fasure. 2005. Screening of crude extracts of six medicinal plants used in South-West Nigeria unorthodox medicine for antimethicillin resistant Staphylococcus aureus. BMC Complementary and Alternative Medicine 5:6. dx.doi.org/10.1186/1472-6882-5-6.

Alnwick D. 2000. Roll Back Malaria - what are the prospects? Bulletin of World Health Orgnaisation. 78(12): 1377.

Ansah, E.K., Gyapong, J.O., Agyepong, I.A., Evans, D.B. 2001. Improving adherence to malaria treatment for children: the use of pre-packed chloroquine tablets vs. chloroquine syrup. Tropical Medicine and International Health 6:496-504.

Aslam, M. 2002. Aspect of Asian medicine and its practice in the west. W.C. Evans (ed) in Trease and Evans' Pharmacognosy.15th Edition. W.B. SaundersCompany (Elsevier), London, U.K.Pp. $469-481$

Atindehou, K.K., M. Koné, C. Terreaux, D. Traore, K. Hostettmann \& M. Dosso 2002.Evaluation of the antimicrobial potential of medicinal plants from Ivory Coast. Phytotherapy Research 16(5): 497-502.

Awudu, O. 2000. Medicinal values of plants. A case of plants around the premises of the Department of Forestry Resources Management, University of Ibadan.Unpublished B.Sc project submitted to the Department of Forestry Resources Management, University of Ibadan.

Buabeng, K.O., Duwiejua, M., Dodoo, N.O.A., Matowe, K.L., Enlund, H. 2007.Self -reported Use of Antimalarial Drugs and Health Facility Management of Malaria in Ghana. Malaria Journal. 6:85.Doi:10.1186/1475-2875-6-85.

Burkill, H.M. 1997. The useful plants of West Tropical Africa Families M - R, Royal Botanic Gardens, Kew Pp 289-310.

Colfer, C.J.P, Sheil, D. Kaimowitz, D. and Kishi, M. 2006. Forest and human health in the tropics. Some important connections. Unasylva 57(224): 3-19.

Dewick, P.M. 2002. Tumor inhibitor. W.C. Evans (ed) in Trease and Evans' Pharmacognosy.15th Edition.Edited by W.C. Evans. W.B. Saunders Company (Elsevier), London, U.K Pp.394-413

Falade,C.O, Ogundiran M.O and Bolaji, M.O. 2006. The influence of cultural perception of causation, complication, and severity of childhood malaria on determinants and treatment 
preventive pathways. International Quarterly of Community Health Education, Journal of Policy and Applied Research 2006. 24.4: 347 - 363.

Healy, M.A. \& M. Aslam. 2002. Homeopathic medicine and aromatherapy. W.C. Evans (ed) in Trease and Evans' Pharmacognosy.15th Edition. W.B. Saunders Company (Elsevier), London, U.K Pp. $460-466$

Kiringe, J.W and Okello, M.M. 2005. Use and availability of tree and shrub resources on massai community range-land near Ambosel: Kenya. African Journal of Range and forage science 22: $37-46$.

Moody, J.O 2007. Traditional medicine. Paper Delivered at the mandatory continuing progressional Development (MCPD) programme, module V, Faculty of Pharmacy, University of Ibadan, Nov. 21-22:1-6.

Muriuki, J. 2006. Forests as pharmacopoeia: identifying new plant based treatments for malaria. Unasylva 224 (57):24-25.

Odugbemi, T. 2008.Pictures and outlines of medicinal plants of Nigeria. University of Lagos press, Lagos, Pp. $56-60$.

Orimadegun A. E. 2010. Malaria in African children, Paper presented at a day seminar on Child Health at College of Medicine University College Hospital Ibadan Nigeria on July 292010.

Osemene, K.P, Elujoba, A.A and Ilori, M.O. 2000. A comparative Assessment of the Herbal and orthodox medicines in Nigeria. Research Journal of Medicinal Sciences5(5):280-285.

Pascaline, J, Charles, M, George, O and Lukhoba C, 2011. An inventory of medicinal plants that the people of Nandi use to treat malaria. Journal of Animal and plant Sciences. Vol 9, issue 3:1192-1200.

Pharmanews, 2010. Cited in A comparative Assessment of the Herbal and orthodox medicines in Nigeria. Research Journal of Medicinal Sciences Vol.5, issue 5:280-285.

Randrianariveiojosia, M, Rasidimanama, V, Rabarison, J, Cheplogoi, P.K, Ratsimbason, M, Mulholland, D.A and Mauciere, P. 2003. Plants traditionally prescribed to treat tazo (malaria) in the eastern region of Madagascar

Ricci, F. 2012.Socio implications of malaria and their relationship with poverty. Mediterrean Journal of Haematology and Infectious Diseases 4(1): 2035 - 3006.

Sindiga, I. 1995. Traditional medicine in Africa: An introduction to Traditional medicine in Africa. Edited by I. Sindiga, C. Nyaigotti-chacha and M.P. Kanunah.East African Educational publishers Ltd. Nawobi.Pp. $1-5$ 
Uzochukwu, B.S, Chiegboka, L.O, Enwereuzo C, Nwosu, U, Okoroafor, D, Onwujekwe, O.E. 2010. Examining Appropriate Diagnostic and Treatment of Malaria: Availability and Use of Rapid Diagnostic Tests and Artemisin- Based Combination Therapy in Public and private Health Facilities in Southeast Nigeria. Bio Medical Centre Public Health. 10:486.

WHO 2006. Africa malaria report. Retrieved on the 10th of March 2009 from http://www.who.int/entity/malaria/ publications/atoz/wmr2006/en/index.html.

WHO 2013.World malaria report; Major progress in fight against malaria, calls for sustained financing. Geneva/Washington DC.

WHO. 1998. Malaria: Know the facts. World Health Organization Newsletter.13(1): 6-7.

Williamson, E.M. 2002. The plant and animal kingdoms as sources of drugs. W.C. Evans (ed) in Trease and Evans' Pharmacognosy.15th Edition.W.B. Saunders Company (Elsevier), London, U.K.Pp 15-41 